
Not for reproduction, distribution or commercial use.

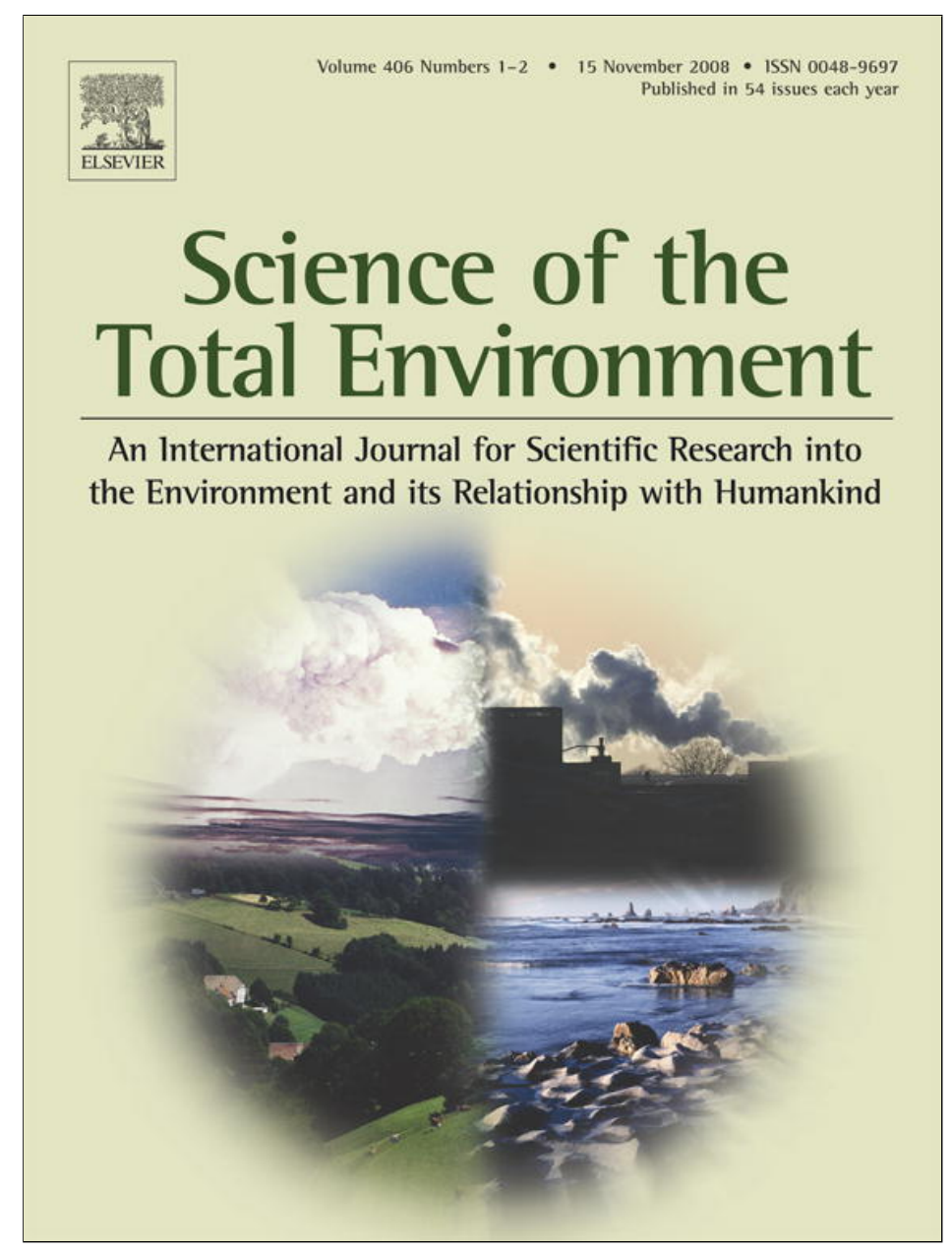

This article appeared in a journal published by Elsevier. The attached copy is furnished to the author for internal non-commercial research and education use, including for instruction at the authors institution and sharing with colleagues.

Other uses, including reproduction and distribution, or selling or licensing copies, or posting to personal, institutional or third party websites are prohibited.

In most cases authors are permitted to post their version of the article (e.g. in Word or Tex form) to their personal website or institutional repository. Authors requiring further information regarding Elsevier's archiving and manuscript policies are encouraged to visit:

http://www.elsevier.com/copyright 


\title{
Bioavailability of heavy metals and their effects on the midgut cells of a phytopaghous insect inhabiting volcanic environments
}

\author{
Armindo Rodrigues $^{a, b, *}$, Luís Cunha ${ }^{a, b}$, André Amaral ${ }^{a, b}$, \\ Jorge Medeiros ${ }^{a, b}$, Patrícia Garcia ${ }^{a, b}$ \\ ${ }^{a}$ Departamento de Biologia, Universidade dos Açores, R. Mãe de Deus, Apt 1422, 9501-855 Ponta Delgada, Portugal \\ ${ }^{\mathrm{b}}$ CIRN, Centro de Investigação de Recursos Naturais, Ponta Delgada, Portugal
}

\section{A R T I C L E I N F O}

\section{Article history:}

Received 29 April 2008

Received in revised form 23 July 2008

Accepted 31 July 2008

Available online 14 September 2008

\section{Keywords:}

Phytophagous insect

Midgut

Heavy metals

Bioavailability

Apoptosis

\begin{abstract}
A B S T R A C T
Organisms living in volcanic environments are chronically exposed to metals, either as particles or associated with gases, from volcanic emissions, being therefore potential sentinels of the effects derived from such exposure. Concentrations of $\mathrm{Ca}, \mathrm{Cd}, \mathrm{Cu}, \mathrm{Mg}, \mathrm{Mn}$, $\mathrm{Pb}, \mathrm{Rb}$, and $\mathrm{Zn}$ were measured in soil, grass (Lolium perenne), and larvae of Pseudaletia uninpuncta captured in sites exposed and non-exposed to volcanic activity. The midgut epithelial cell morphometry and apoptosis of $P$. unipuncta larvae were also analyzed. Larvae from the site with volcanic activity showed higher levels of $\mathrm{Cu}, \mathrm{Mn}, \mathrm{Rb}$ and $\mathrm{Zn}$. Metals such as $\mathrm{Pb}, \mathrm{Cd}$ and $\mathrm{Mg}$ levels of $\mathrm{P}$. unipuncta larvae were similar between sites. Apoptosis was higher in cells from digestive epithelium of larvae exposed to volcanic activity. Soils and grass not exposed to volcanic activity showed higher levels for most of the analyzed elements with the exception of $\mathrm{Rb}$. Such result when compared with metal levels of larvae may reveal that bioavailability of elements differs between sites. The higher levels of Cd, $\mathrm{Zn}$ and $\mathrm{Mg}$ in soils and grass from the site with no volcanic activity are probably related to the severe artificial fertilization in the studied pastures. Such result, when compared with metal levels of larvae, suggest that the bioavailability of metals differs between sites.
\end{abstract}

(c) 2008 Elsevier B.V. All rights reserved.

\section{Introduction}

In São Miguel Island (Azores, Portugal) volcanic activity is manifested, among other ways, by the occurrence of hydrothermal vents, and soil degassing (Cruz, 2003; Ferreira et al., 2005). Consequently, organisms living in such environment may be continually exposed to metals, either as particles or associated with gases (Hansell et al., 2006). The association between changes in the digestive epithelium and the occurrence of apoptosis under chronic metal and metalloid exposure, originated by volcanic activity, has been previously found in terrestrial (e.g., earthworms, and snails) and marine invertebrates (e.g., limpets) (Amaral and Rodrigues, 2005; Zaldibar et al., 2006; Cunha et al., 2008). Thus, it is important to look for organisms that can be used as biological indicators or sentinels for the presence of those pollutants under such conditions, and in which one can rapidly measure several biomarkers of exposure and/or effects.

The relationship between the accumulation of metals and their biomagnification in edible plants, insects, such as Lepidoptera larvae, and higher consumers, such as predators, has been shown in recent studies (Vickerman and Trumble, 2003; Dauwe et al., 2004; Mulder and Breure, 2006). Such studies indicate the important role of insects as links in metal transport

\footnotetext{
* Corresponding author. Laboratório de Histologia, Departamento de Biologia, Universidade dos Açores, R. Mãe de Deus, Apt 1422, $9501-855$ Ponta Delgada, Portugal. Tel.: +351 296650 109; fax: +351 296650100.

E-mail address: rodrigues@uac.pt (A. Rodrigues).
} 
$25^{\circ} 30^{\prime} 0^{\prime \prime} \mathrm{V}$

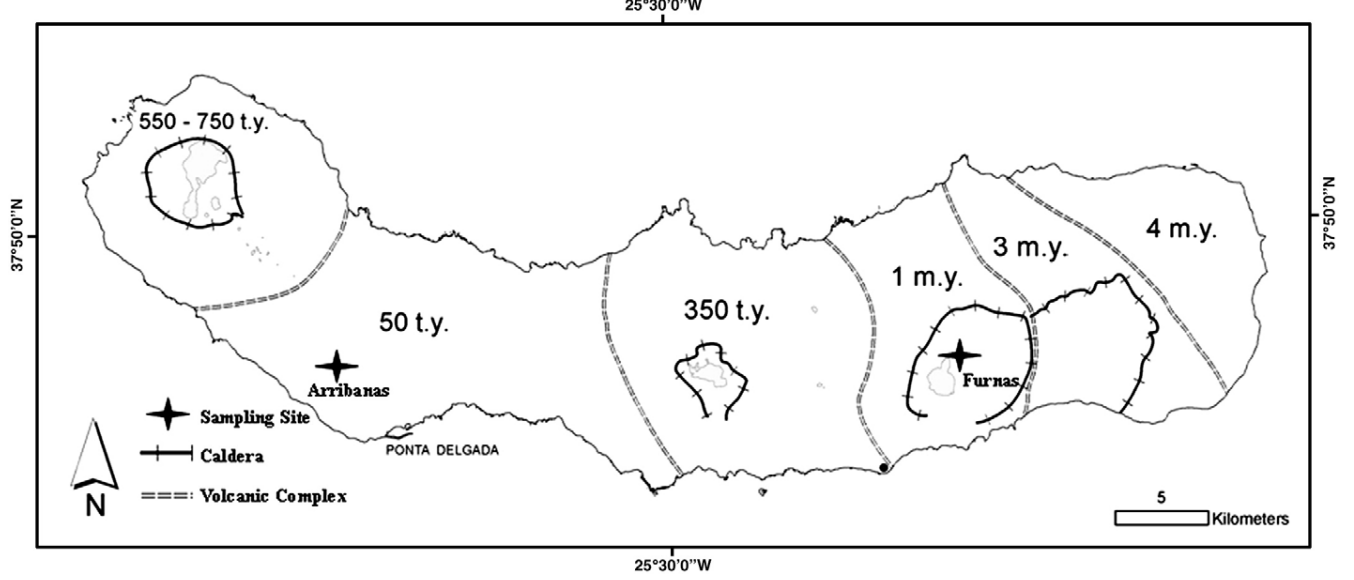

Fig. 1-Sampling sites in São Miguel Island (Azores). Geological age expressed in million of years (m.y.) and thousands of years (t.y.). 
chains between trophic levels in many food webs. Moreover, insects possess several mineral bioaccumulation structures in various organs, such as the midgut, being therefore of particular interest among invertebrates to what metal storage and effects is concerned (Ballan-Dufrançais, 2002).

The armyworm, Pseudaletia (=Mythimna) unipuncta (Haworth) (Lepidoptera: Noctuidae), is an important cosmopolitan pest of cereal which is known to forage crops in North America (McNeil et al., 2000) and Europe (Bues et al., 1986). In the Azores, this pest is a polivoltine species (Raposo et al., 2003), and its larvae are usually found in pastures throughout all seasons (Vieira et al., 2004). Since the larval stages develop and feed usually on grass within a restricted area inside the pastures (Reis et al., 2003; Silva et al., 2003), these organisms, their food and inhabiting soils could be used to evaluate bioavailability and biotransference of trace metals in extreme environments of volcanic origin. Bearing this in mind, and since it is known that metals can promote and originate changes in the composition and diameter of digestive epithelia of several invertebrates that can be measured through variations in the mean radial epithelial thickness (Amaral et al., 2006a; Marigomez et al., 2006; Cunha et al., 2008), but also with apoptosis, another cellular response that may be triggered by metal stress. Apoptosis is involved in cell turnover, and has been suggested as a biomarker of the effect of bioavailable metals when its rates vary from normal (Amaral and Rodrigues, 2005; Cunha et al., 2008). The present study aimed to determine whether larvae exposed and not exposed to volcanic activity show distinct metal body burdens, but also to analyze the effects of such metals on the midgut cell morphometry and apoptosis.

\section{Materials and methods}

\subsection{Experimental design and sampling sites}

P. unipuncta larvae were collected early in the summer (late Juneearly July 2007) by randomly sampling two distinct areas of pasture grass within each site (Silva et al., 2003), until 20 larvae of the third, fourth and fifth instar were obtained. Larvae were collected from two sites separated $50 \mathrm{~km}$ in São Miguel Island (Azores) (Fig. 1), and differing in the presence or not of hydrothermal volcanic activity: (i) Água Azeda which is a natural pasture, chronically exposed to soil degassing and hydrothermal vents; and (ii) Arribanas, which do not show volcanic activity and is a heavily and artificially fertilized pasture. From each site, a set of 10 larvae were captured for chemical analyses, and another set of 10 larvae were collected for histological processing and apoptosis tests. For each site, two samples (20 m apart) of Lolium perenne L. leaves ( $150 \mathrm{~g}$ wet weight each) and two of soil (500 g wet weight each, collected from an area of $200 \mathrm{~m}^{2}$ and $20 \mathrm{~cm}$ depth) were collected for the chemical analysis of metal contents and soil properties. Soils from the active volcanic site had lower $\mathrm{pH}$ and clay-silt percentage than soils from the non-active volcanic site (Table 1).

\subsection{Metal analysis}

The soft tissues of the thorax and the abdomen of $\mathrm{P}$. unipuncta larvae were dried $\left(130^{\circ} \mathrm{C}\right)$ for $48 \mathrm{~h}$, digested in aqua regia at $95^{\circ} \mathrm{C}$ for $2 \mathrm{~h}$, and then microwave digested inside closed vessels for
Table 1-Physico-chemical properties of the analyzed soils from the site with volcanic activity (Água Azeda) and the other with no volcanic activity (Arribanas)

\begin{tabular}{lcccl} 
Soil & & \multicolumn{2}{c}{$\%$} & \\
\cline { 3 - 4 } & $\mathrm{pH}\left(\mathrm{H}_{2} \mathrm{O}\right)$ & Clay-silt & Moisture & \\
\hline Água Azeda & 5.7 & 30.88 & 31.78 & Amaral et al. 2006b \\
Arribanas & 6.2 & 64.67 & 34.9 & Unpublished data
\end{tabular}

$2 \mathrm{~min}$. Resultant sample solutions were diluted and analyzed on a Finnegan Mat Element 2 High Resolution ICP/MS (Actlabs, Canada) for the quantification of $\mathrm{Ca}, \mathrm{Cd}, \mathrm{Cu}, \mathrm{Mg}, \mathrm{Mn}, \mathrm{Pb}, \mathrm{Rb}$ and $\mathrm{Zn}$. The same procedure was used for soil and grass samples from each site. The concentrations are expressed in $\mu \mathrm{g} / \mathrm{g}$ (dry weight). For quality control, internal standards and reference materials were run together with the samples, and no less than six different reference materials covering all the elements in study were used. Duplicate samples were also used in order to determine precision of the analysis. For each element, a minimum of three standards were used to cover the analytical working range of the instrument. Ultrapure water was used to prepare blanks and calibration standards, and three replicate assessments were performed for each sample.

A pool of several fertilizers frequently used in pastures of the site with no volcanic activity (Arribanas) was also analyzed.

\subsection{Midgut epithelial cell morphometry and apoptosis}

The digestive tract of each 10 larvae per site was used for light microscopy, morphometry and apoptosis studies (TUNEL test). Larvae were fixed in neutral-buffered formaldehyde, dehydrated in an increasing series of ethanol, cleared in methylbenzoate, rinsed in benzene, and embedded in paraffin. Histological sections of the midgut were cut with $5 \mu \mathrm{m}$ thickness and stained with hematoxylin and eosin (Martoja and Martoja-Pierson, 1970).

To quantify the radial thickness of the midgut digestive epithelium, a planimetric procedure was applied on sections of the digestive tube (Amaral et al., 2006a). From each individual, two tissue sections, $25 \mu \mathrm{m}$ apart from each other, were used by taking a mean value of four measures in each section, for a total of eight measurements per individual, while their digestive tract profiles were captured using a CoolSNAP-cf camera (Photometrics GmbH, Germany) coupled to a light microscope, and analyzed with Image Pro-Plus 5.0 software (Media Cybernetics, Silver Springs). For statistical analysis, it was considered the average of the eight measurements per individual, being each individual a replicate.

The detection of apoptotic nuclei in the digestive tract was performed using a DeadEnd ${ }^{\mathrm{TM}}$ kit (Promega, USA). Briefly, two tissue sections ( $25 \mu \mathrm{m}$ apart from each other) from the midgut digestive epithelium were dewaxed and rehydrated. Sections were then washed in phosphate buffered saline and treated with $20 \mu \mathrm{g} / \mathrm{ml}$ proteinase $\mathrm{K}$ for $20 \mathrm{~min}$ at room temperature. DNA of the tissue sections was labeled at 3 ' ends with biotin-dUTP by incubation with the reaction buffer containing terminal deoxynucleotidyl transferase, for $60 \mathrm{~min}$ at $37^{\circ} \mathrm{C}$. Tissues were then treated with $3 \%$ hydrogen peroxide for $5 \mathrm{~min}$, and incubated $30 \mathrm{~min}$ at room temperature with streptavidin horseradish peroxidase to detect biotinylated nucleotides. Diaminobenzidine 
reacted within the labeled nuclei to generate an insoluble brown substrate at the site of DNA fragmentation. As a negative control, terminal deoxynucleotidyl transferase was replaced by bidistilled water (results not shown). Finally, sections were counterstained with $0.3 \%$ methyl green to allow the morphological evaluation and characterization of normal and apoptotic cells. The percentage of apoptotic nuclei was graded as follows: 0 (no staining); 1 (>0 a 50\%); 2 (>50\%).

\subsection{Statistical analysis}

Differences in cell morphometry as well as the extent of apoptotic nuclei in the midgut epithelium were examined by a t-test assuming equal variances and considered as significant when $p \leq 0.05$. Statistical analyses were made using SPSS 15.0 (SPSS Inc., Chicago, U.S.A.).

\section{Results}

\subsection{Metal analysis}

All measured elements were detectable in soil, grass and larvae samples from both sites (Table 2). Soils from the site with no volcanic activity (Arribanas) showed higher levels of all tested trace elements, except Rb (higher in Água Azeda) and $\mathrm{Zn}$ (values were similar in both sites). In Arribanas, higher concentrations of $\mathrm{Cd}, \mathrm{Mg}$ and $\mathrm{Zn}$ were also observed in grass samples, being the $\mathrm{Cd}$ concentration seven times higher than in the samples from Água Azeda (Table 2). Although richness of Zn was particularly higher in the Arribanas grass, larvae from the pasture with volcanic activity (Água Azeda) revealed a higher concentration of this metal. Also, a higher concentration of $\mathrm{Cu}$ was detected in larvae from Água Azeda, while in grass concentrations from both sites were similar (Table 2). Rb was the only element always present at higher concentrations in soil, grass and larvae samples collected in the pasture with volcanic activity (Table 2).

Although Mn concentration in soil from Arribanas was almost two fold higher, grass and larvae samples from the site with volcanic activity showed concentrations two- to threefold higher than those from the former site.

Metal content of the fertilizers can be seen in Table 3.

Table 2 - Concentrations of metals ( $\mu \mathrm{g}$ element/g of dry weight) measured by HR-ICP/MS in the soils, grass and the larvae of P. unipuncta from a site with volcanic activity (Água Azeda) and other with no volcanic activity (Arribanas)

\begin{tabular}{|c|c|c|c|c|c|c|}
\hline \multirow[t]{3}{*}{ Elements } & \multicolumn{2}{|c|}{ Soil } & \multicolumn{2}{|c|}{ Grass } & \multicolumn{2}{|c|}{ Larvae } \\
\hline & \multicolumn{2}{|c|}{$\begin{array}{l}\text { Volcanic } \\
\text { activity }\end{array}$} & \multicolumn{2}{|c|}{$\begin{array}{l}\text { Volcanic } \\
\text { activity }\end{array}$} & \multicolumn{2}{|c|}{$\begin{array}{l}\text { Volcanic } \\
\text { activity }\end{array}$} \\
\hline & No & Yes & No & Yes & No & Yes \\
\hline $\mathrm{Ca}$ & 12,328 & 7611 & 6315 & 3295 & 1565 & 1390 \\
\hline $\mathrm{Cd}$ & 0.8 & $<0.5$ & 0.7 & $<0.1$ & 0.1 & 0.1 \\
\hline $\mathrm{Cu}$ & 29 & 15 & 9 & 8 & 15.2 & 28.1 \\
\hline $\mathrm{Mg}$ & 6500 & 3400 & 3600 & 1415 & 4770 & 4690 \\
\hline $\mathrm{Mn}$ & 2400 & 1400 & 96 & 314 & 110.2 & 287 \\
\hline $\mathrm{Pb}$ & 54 & 42.5 & 0.1 & 0.1 & 0.1 & 0.1 \\
\hline $\mathrm{Rb}$ & 83 & 187 & 66.7 & 128 & 30.9 & 34.8 \\
\hline $\mathrm{Zn}$ & 160 & 153 & 94 & 33 & 165.3 & 189 \\
\hline
\end{tabular}

Table 3 - Average concentrations of metals ( $\mu \mathrm{g}$ element/g of dry weight) measured by ICP/MS of several fertilizers that are frequently used in pastures of the site with no volcanic activity (Arribanas)

\begin{tabular}{lc} 
Elements & Fertilizers \\
\hline $\mathrm{Ca}$ & 41,880 \\
$\mathrm{Cd}$ & 9.7 \\
$\mathrm{Cu}$ & 16.7 \\
$\mathrm{Mg}$ & 2433.3 \\
$\mathrm{Mn}$ & 17.3 \\
$\mathrm{~Pb}$ & 3.5 \\
$\mathrm{Rb}$ & $<15$ \\
$\mathrm{Zn}$ & 176.3
\end{tabular}

\subsection{Midgut cell morphometry and apoptosis}

Mean epithelium thickness showed highest values in larvae from Água Azeda $[56.04 \pm 1.95( \pm$ S.E.) $\mu \mathrm{m}]$. The mean epithelium thickness of larvae from Arribanas was $51.84 \pm 2.42( \pm$ S.E.) $\mu \mathrm{m}$. Nevertheless, the mean digestive epithelium thickness did not differ significantly between both sites ( $\mathrm{t}$-value $=-1.35 ; p=0.185$ ).

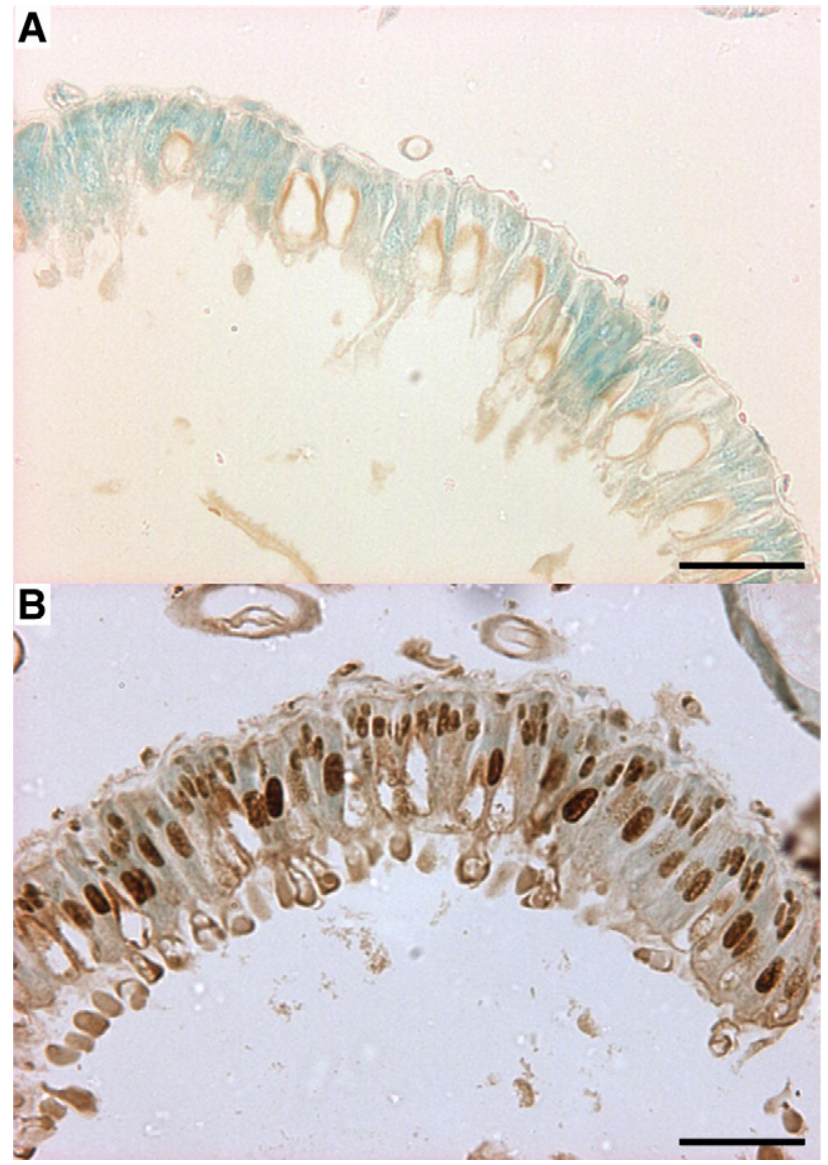

Fig. 2-A-Digestive epithelium of a specimen from a site free of volcanic activity (Arribanas), stained with TUNEL test, showing no apoptotic nuclei. B - Digestive epithelium of a specimen from a site with volcanic activity (Água Azeda) stained with TUNEL test, showing numerous apoptotic nuclei. Apoptotic nuclei stained brown. Scale bars $=\mathbf{5 0} \mu \mathrm{m}$. (For interpretation of the references to colour in this figure legend, the reader is referred to the web version of this article.) 


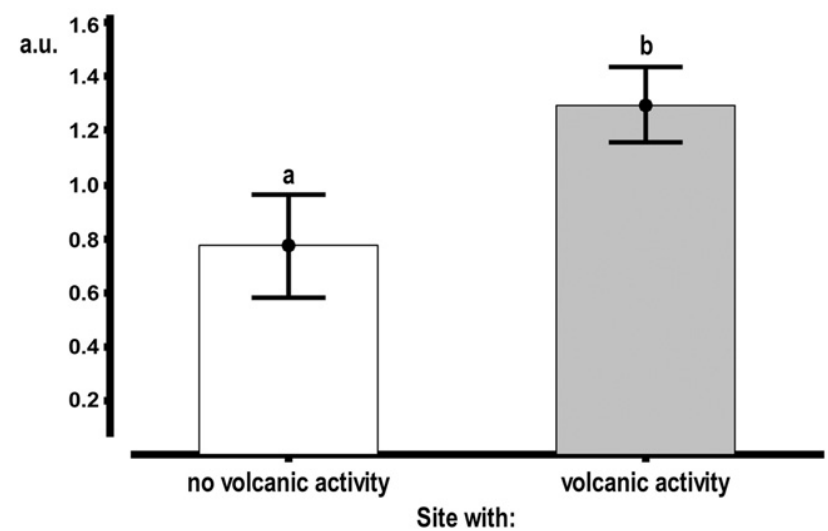

Fig. 3-(Semi)quantification of apoptotic nuclei [mean \pm SE] of digestive epithelium of Pseudaletia unipuncta from a site with volcanic activity (Água Azeda) and other with no volcanic activity (Arribanas); a.u.= arbitrary units. Different letters over the bars indicate significant differences at $\boldsymbol{p}<0.05$ (t-test).

Differences in apoptotic levels found in these larvae were not due to larval stages variability, which revealed no significant differences ( $F=0.77 ; p=0.473$, two-way ANOVA). Also, neither the interaction between larval stages and sites was significant $(F=1.38 ; p=0.268$, two-way ANOVA). Pooled data from both sites revealed that apoptosis was more prominent in cells from the digestive epithelium of $P$. unipuncta larvae captured in the site with volcanic activity (Água Azeda) (Fig. 2), revealing significant differences (t-value $=-2.31 ; p=0.027$ ) (Fig. 3).

\section{Discussion}

Soil and grass samples from environment without volcanic activity showed higher concentrations of most of the considered elements probably due to soil enrichment by fertilizers (see Table 3). In fact, in all agricultural areas of São Miguel Island, including Arribanas, artificial fertilizers are applied to pastures in an uncontrolled manner, often inappropriately and in large amounts, which are also the cause of severe eutrophication of ponds and lakes (Depledge et al., 1992). Although concentration of Cd was seven times higher in the grass from the inactive volcanic site, the levels of Cd in larvae were similar between sites, suggesting the occurrence of detoxification processes that lower the Cd levels in the insect body. According to Borowska et al. (2004) a possible via of detoxification of xenobiogenetic metals (as $\mathrm{Cd}$ and $\mathrm{Pb}$ ) in insects is by allocating metals to the surface of the chitinous exoskeleton (cuticule), which is periodically shed during larval molts. On the other hand, in the active volcanic site the higher concentration of $\mathrm{Cd}$ in larvae than in the grass could be due to other uptake via (e.g., cutaneous and/or respiratory) related to the increased bioavailability of this element in this extreme environment, as previously suggested by Amaral et al. (2007) for mice (Mus musculus).

In contrast with heavy metal contents in soils and grass, larvae from the active volcanic environment presented higher concentrations of $\mathrm{Cu}, \mathrm{Mn}, \mathrm{Rb}$ and $\mathrm{Zn}$, similarly to that observed by Cunha et al. (2008) in the digestive gland of marine limpets from shallow water hydrothermal vents. Higher levels of $\mathrm{Rb}$ in organisms after volcanic exposure are not uncommon (Widom et al., 1997; Claude-Ivanaj et al., 2001; Durand et al., 2004), so the presence of $\mathrm{Rb}$ in samples from Água Azeda were expected, and thus the levels of this trace element could be used as a biomarker of exposure to volcanic environments, as previously suggested (Durand et al., 2004; Amaral et al., 2008). In larvae from Água Azeda, values observed for $\mathrm{Cu}$ and $\mathrm{Zn}$ were particularly high and clearly greater than the observed by Dauwe et al. (2004) for Lepidoptera larvae (22.5 and $157.2 \mu \mathrm{g} / \mathrm{g}$ for $\mathrm{Cu}$ and $\mathrm{Zn}$, respectively) collected in a site near $(0-0.35 \mathrm{~km}) \mathrm{a}$ metallurgic plant, thus heavily contaminated by heavy metals. Furthermore, according to Borowska et al. (2004) and contrarily to the observed, insects should be more efficient in the elimination of biogenetic ( $\mathrm{Cu}$ and $\mathrm{Zn}$ ) than xenobiogenetic elements $(\mathrm{Cd}$ and $\mathrm{Pb})$. Such results suggest that the active volcanic environment, characterized by a lower $\mathrm{pH}$ and a lesser clay-silt percentage (see Table 1), and a damp atmosphere rich in sulfur gases, may increase the availability of $\mathrm{Cu}$ and $\mathrm{Zn}$ to the larvae, as suggested in previous studies by Amaral et al. (2006a, 2007). This result is exemplified by the concentrations of $\mathrm{Zn}$ in the Arribanas grass and larvae, which contrast with $\mathrm{Zn}$ levels of those from the pasture with volcanic activity (Água Azeda), indicating sources of contamination other than the ingestion of grass. Dermal absorption of this element from the air resulting from the volcanic degassing is one of the possible explanations for this. Also, the higher concentration of Cu in larvae from Água Azeda may be explained by a similar via of contamination.

Contrarily to the concentrations of $\mathrm{Mn}$ observed for soil samples, the higher levels of this element in grass $(314 \mu \mathrm{g} / \mathrm{g})$ and larvae $(287 \mu \mathrm{g} / \mathrm{g})$ from the site with volcanic activity suggest a higher availability of this element for plants due to the lower concentration of $\mathrm{Mg}$ and $\mathrm{Ca}$ in soil. This phenomenon could be potentiated by the lower $\mathrm{pH}$ of the soil in this local (Table 1), as it was pointed out by Davis (1996) and CTAHR-Cooperative Extension Service (1998). According to data published by Lei et al. (2007), Mn concentration in grass samples from the active volcanic environment configures a high Mn chronic stress situation, being above Mn phytotoxicity thresholds for sheep fescue species (Festuca ovina) (>200 ppm) (Paschke et al., 2005). On the other hand, in Arribanas $\mathrm{Ca}$ and $\mathrm{Mg}$ application by manual fertilization could result in an important reduction in Mn uptake in grass, as sustained by Davis (1996).

Morphometric changes in digestive tissues have been used as common biomarkers for pollution exposure of anthropogenic and volcanic origin (Marigomez et al., 1996; Vega et al., 1989; Amaral et al., 2006a; Cunha et al., 2008). However, the present study shows that this trait is not reliable as a marker of the chronic metal exposure of $P$. unipuncta larvae, since the mean digestive epithelium thickness did not differ between both sites.

The presence of $\mathrm{Cu}$ has been shown to disturb the elemental composition of the epithelial cells of housefly midgut (i.e., cellular concentration decreases of $\mathrm{K}, \mathrm{Mg}, \mathrm{P}$, and $\mathrm{S})$, particularly after the exposure to $5 \mu \mathrm{g} / \mathrm{g}$ of $\mathrm{Cu}$ in the larvae rearing medium (Tylko et al., 2005). Since levels of $\mathrm{Cu}$ in $\mathrm{P}$. unipuncta larvae were considerably high, especially for larvae from the active volcanic environment $(28 \mu \mathrm{g} / \mathrm{g})$, it is possible that the elemental composition of the midgut cells was disturbed, increasing the apoptotic events as a possible via of detoxification. Loeb et al. (2000) have demonstrated that 
apoptosis is probably a normal method for biological disposal of older differentiated midgut cells of Lepidoptera larvae (Heliothis virescens) and that when midgut cell cultures are exposed to adverse environments, such as poisonous media, down-regulation of cell populations is induced by apoptosis. Nevertheless, programmed cell death and autophagy are natural and intense processes during larval development of lepidoptera (Tettamanti et al., 2007), which were considered during data treatment and analysis. Differences in apoptotic levels found in the larvae were not due to variability between larval stages nor the interaction between larval stages and sites. Therefore, pooled data (Zar, 2007) was used to compare both sites, which revealed that apoptosis was more prominent in cells from the digestive epithelium of P. unipuncta larvae captured in the site with volcanic activity (Água Azeda).

On the other hand, Zhang et al. (2001) refer that in contrast to other metals, $\mathrm{Zn}$ is not deposited efficiently in cells, being a less potent inducer of metallothioneins in insects (Diptera), which are important proteins involved in metal detoxification. Thus, Zn levels could act synergistically with other metals, such as Cd and $\mathrm{Cu}$, in promoting apoptosis. Since active volcanic environment seems to be a source of chronic metal stress, particularly $\mathrm{Zn}$, the higher levels of apoptosis found in organisms from Água Azeda may be again associated to apoptotic detoxification processes as a cellular response and adaptation to this particular extreme environment of volcanic origin.

\section{Acknowledgements}

This study was financially supported by CIRN (University of the Azores), and DRCT (Government of the Azores). André Amaral was supported by a Postdoctoral grant from FCT (SFRH/BPD/27136/2006) and Luis Cunha by a Doctoral grant from DRCT (M312/F/029/2007).

\section{Appendix A. Supplementary data}

Supplementary data associated with this article can be found, in the online version, at doi:10.1016/j.scitotenv.2008.07.069.

\section{R E F E R E N C E S}

Amaral AFS, Rodrigues AD. Metal accumulation and apoptosis in the alimentary canal of Lumbricus terrestris as a metal biomarker. Biometals 2005;18:199-206.

Amaral AFS, Arruda M, Cabral S, Rodrigues AS. Essential and non-essential trace metals in scalp hair of men chronically exposed to volcanogenic metals in the Azores, Portugal. Environ Int 2008. doi:10.1016/j.envint.2008.03.013.

Amaral A, Cabral C, Guedes C, Rodrigues A. Apoptosis, metallothionein, and bioavailable metals in domestic mice (Mus musculus L.) from a human-inhabited volcanic area. Ecotoxicology 2007;16:475-82.

Amaral A, Cruz JV, Cunha RT, Rodrigues AS. Baseline levels of trace metals in volcanic soils of the Azores (Portugal). Soil Sediment Contam 2006b;15(2):123-30.

Amaral A, Soto M, Cunha R, Marigomez I, Rodrigues A. Bioavailability and cellular effects of metals on Lumbricus terrestris inhabiting volcanic soils. Environ Pollut 2006a;142:103-8.

Ballan-Dufrançais C. Localization of metals in cells of Pterygote insects. Microsc Res Tech 2002;56:403-20.

Borowska J, Sulima B, Nilińska M, Pyza E. Heavy metal accumulation and its effects on development, survival and immuno-competent cells of the housefly Musca domestica from closed laboratory populations as model organism. Fresenius Environ Bull 2004;13(12a):1402-9.

Bues R, Poitout S, Anglade P, Robin JC. Cycle évolutif et hivernation de Mythimna (Syn. Pseudaletia) unipuncta Haw. (Lep. Noctuidae) dans le sud de la France. Acta Oecol 1986;7:151-6.

Claude-Ivanaj C, Joron JL, Allègre CJ. ${ }^{238} \mathrm{U}-{ }^{230} \mathrm{Th}-{ }^{226} \mathrm{Ra}$ fractionation in historical lavas from the Azores: long-lived source heterogeneity vs. metasomatism fingerprints. Chem Geol 2001;176:295-310.

Cruz JV. Groundwater and volcanoes: examples from de Azores archipelago. Environ Geol 2003;44:343-55.

CTAHR-Cooperative Extension Service. Managing manganese toxicity in former sugarcane soils on Oahu. Soil Crop Manage 1998;1:1-7.

Cunha L, Amaral A, Medeiros V, Martins GM, Wallenstein FFMM, Couto RP, Neto AI, Rodrigues A. Bioavailable metals and cellular effects in the digestive gland of marine limpets living close to shallow water hydrothermal vents. Chemosphere 2008;71:1356-62.

Dauwe T, Janssens E, Bervoets L, Blust R, Eens M. Relationships between metal concentrations in great tit nestlings and their environment and food. Environ Pollut 2004;131:373-80.

Davis JG. Soil pH and magnesium effects on manganese toxicity in peanuts. J Plant Nutr 1996;19(4):535-50.

Depledge MH, Weeks JM, Martins AF, Cunha RT, Costa A. The Azores Exploitation and pollution of the coastal ecosystem. Mar Pollut Bull 1992;24(9):433-5.

Durand M, Florkowski C, George P, Walmsley T, Weinstein P, Cole J. Elevated trace element output in urine following acute volcanic gas exposure. J Volcanol Geotherm Res 2004;134:139-48.

Ferreira T, Gaspar JL, Viveiros F, Marcos M, Faria C, Sousa F. Monitoring of fumarole discharge and $\mathrm{CO} 2$ soil degassing in the Azores: contribution to volcanic surveillance and public health risk assessment. Ann Geophys 2005;48:787-95.

Hansell AL, Horwell CJ, Oppenheimer C. The health hazards of volcanoes and geothermal areas. Occup Environ Med 2006;63:149-56.

Lei Y, Chen K, Tian X, Korpelainen H, Li C. Effect of Mn toxicity on morphological and physiological changes in two Populus cathayana populations originating from different habitats. Trees 2007;21:569-80.

Loeb MJ, Hakim RS, Martin P, Narang N, Goto S, Takeda M. Apoptosis in cultured midgut cells from Heliothis virescens larvae exposed to various conditions. Arch Insect Biochem Physiol 2000;45:12-23.

Marigomez I, Soto M, Cancio I, Orbea A, Garmendia L, Cajaraville MP. Cell and tissue biomarkers in mussel, and histopathology in hake and anchovy from Bay of Biscay after the Prestige oil spill (Monitoring Campaign 2003). Mar Pollut Bull 2006;53:287-304.

Marigomez I, Soto M, Kortabitarte M. Tissue level biomarkers and biological effect of mercury on sentinel slugs, Arion ater. Arch Environ Contam Toxicol 1996;31:54-62.

Martoja R, Martoja-Pierson M. Técnicas de Histología Animal. Barcelona: Toray Masson SA; 1970. 350 pp.

McNeil JN, Miller D, Laforge ME, Cusson M. The biosynthesis of juvenile hormone, its degradation and titres in females of the true armyworm: a comparison of migratory and non-migratory populations. Arch Insect Biochem Physiol 2000;32:575-84.

Mulder C, Breure AM. Impact of heavy metal pollution on plants and leaf-miners. Environ Chem Lett 2006;4:83-6.

Paschke MW, Valdecantos A, Redente EF. Manganese toxicity thresholds for restoration grass species. Environ Pollut 2005;135:313-22. 
Raposo F, Oliveira L, Garcia P. Susceptability to insecticides of Glyptapanteles militaris (Hymenoptera: Braconidae), a parasitoid of Pseudaletia unipuncta (Lepidoptera: Noctuidae). Biocontrol Sci Technol 2003;13:261-7.

Reis J, Oliveira L, Garcia P. Effects of the larval diet of Pseudaletia unipuncta (Lepidoptera: Noctuidae) on the performance of the parasitoid Glyptapanteles militaris (Hymenoptera: Braconidae). Environ Entomol 2003;32(1):180-6.

Silva L, Vieira V, Tavares J. Sampling plans for Pseudaletia unipuncta (Haworth) (Lep. Noctuidae) larvae in Azorean pastures. Environ Entomol 2003;35:1211-8.

Tettamanti G, Grimaldi A, Casartelli M, Ambrosetti E, Ponti B, Congiu T, Ferrarese R, Rivas-Pena M, Pennacchio F, Eguileor M. Programmed cell death and stem cell differentiation are responsible for midgut replacement in Heliothis virescens during prepupal instar. Cell Tissue Res 2007;330(2):345-59.

Tylko G, Banach Z, Borowska J, Niklinska M, Pyza E. Elemental changes in the brain, muscle, and gut cells of the housefly, Musca domestica, exposed to heavy metals. Microsc Res Tech 2005;66:239-47.

Vega MM, Marigomez JA, Angulo E. Quantitative alterations in the structure of the digestive cell of Littorina littorea on exposure to cadmium. Mar Biol 1989;103:547-53.
Vickerman DB, Trumble JT. Biotransfer of selenium: effects on an insect predator, Podisus maculiventis. Ecotoxicology 2003;12:497-504.

Vieira V, Oliveira L, Garcia P, Tavares J. Assessment of Pseudaletia unipuncta (Haworth) (Lep. Noctuidae) populations in Azorean pastures by light and pheromone traps. Arquipélago 2004;21A:33-42.

Widom E, Carlson RW, Gill JB, Schmincke HU. Th-Sr-Nd-Pb isotope and trace element evidence for the origin of the Sao Miguel, Azores, enriched mantle source. Chem Geol 1997;140:49-68.

Zaldibar B, Rodrigues A, Lopes M, Amaral A, Marigomez I, Soto M. Freshwater molluscs from volcanic areas as model organisms to assess adaptation to metal chronic pollution. Sci Total Environ 2006;371:168-75.

Zar JH. Biostatistical analysis. Fifth ed. Upper Saddle River, NJ, USA: Prentice-Hall, Inc.; 2007. 960 pp.

Zhang B, Egli D, Georgiev O, Schaffner W. The Drosophila homolog of mammalian zinc finger factor MTF-1 activates transcription in response to heavy metals. Mol Cell Biol 2001;21:4505-14. 